Limnological Review (2011) 11, 2: 59-68

DOI 10.2478/v10194-011-0027-z

\title{
Lead in the environment of Lake Wigry (NE Poland)
}

\author{
Urszula Aleksander-Kwaterczak ${ }^{1}$, Anna Kostka ${ }^{2}$ \\ Department of General Geology, Environment Protection and Geotourism, Faculty of Geology, Geophysics and Environment Protec- \\ tion, AGH University of Science and Technology, 30-059 Krakow, Mickiewicza 30, Poland,

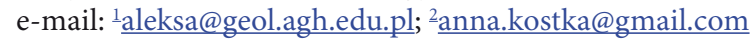

\begin{abstract}
Analysis was performed for lead content in the sediments of Lake Wigry (NE Poland), taking into account lithology, basic chemical component content and physical characteristics of sediment, Several hundred sediment samples from different parts of the lake and peatland around the lake, were collected. Their locations were determined by GPS and the depth of sediment by echosounder. The surface layer $(0-10 \mathrm{~cm})$ of sediment and sediment cores were taken to determine the spatial and vertical distribution of $\mathrm{Pb}$. Concentrations of lead in the surface sediment range from 2.52 to $469 \mathrm{mg} \mathrm{kg}^{-1}$. One of the most important factors influencing spatial distribution of $\mathrm{Pb}$ is sediment type. The highest content of $\mathrm{Pb}$ was found in samples of organic gyttja and the lowest in clastic sediment samples. Strong positive linear correlation $(\mathrm{r}=0.7)$ between organic matter content and $\mathrm{Pb}$ concentration in sediment was observed. It may be the result of simple bio-accumulation of lead. A large influence of sediment location on $\mathrm{Pb}$ distribution was found. The largest concentration of this element was found in sediment of the Wigry Basin. The major part of $\mathrm{Pb}$ accumulates in the surface layer of sediment.
\end{abstract}

Key words: Lake Wigry, carbonate sediment, lead, pollution

\section{Introduction}

Bottom sediments accumulate substances constantly precipitating into the reservoir and are a valuable source of information about physical, chemical and biological processes taking place in the lake and its catchment area. The content of metals in sediment is one of the most sensitive and widely used indicators of pollution (Maclin and Klimek 1992; AleksanderKwaterczak 2007). Human activity introduces numerous potentially hazardous trace elements into the water environment. The highest contamination of sediment usually occurs in the drainage basin affected by excavation and processing of polymetallic ores. As a result of the progressive pollution of water reservoirs, recently formed sediments are characterized by increased content of heavy metals. The chemical composition of surface layers of unconsolidated sediment, especially the concentration of trace elements and the content of organic pollutants content, continuously changes over time. It is caused by the decomposition of organic matter contained in sediment and the exchange of components between water and sediment which is associated with changes in physical-chemi- cal conditions (temperature, $\mathrm{pH}$, Eh, salinity) (Maclin and Klimek 1992; Bojakowska 1995; Nriagu 1996; Aleksander-Kwaterczak 2007).

Nowadays, many lakes, both in Poland and in the world have turned from valuable natural and economic objects into reservoirs requiring constant protection. This is mainly due to incorrect use of lakes and their pollution. Hence the environment is no longer able to clean itself. Among the main threats to the ecological status of lakes are: declining of water resources, eutrophication and degradation of ecosystems, increasing acidity of water and its contamination by toxic substances (Marszalewski 2005).

\section{Study area}

Lake Wigry, located in NE Poland within the borders of Wigierski National Park, is one of the biggest, one of the deepest and one of the most capacious lakes in Poland (Jańczak 1999). Its shoreline is very diversified (Fig. 1), its bathymetry complicated and well known only in selected parts of the lake (Osadczuk et al. 2006; Rutkowski et al. 2009a). Lake Wigry waters are mainly supplied by the Czarna Hańcza River flowing 


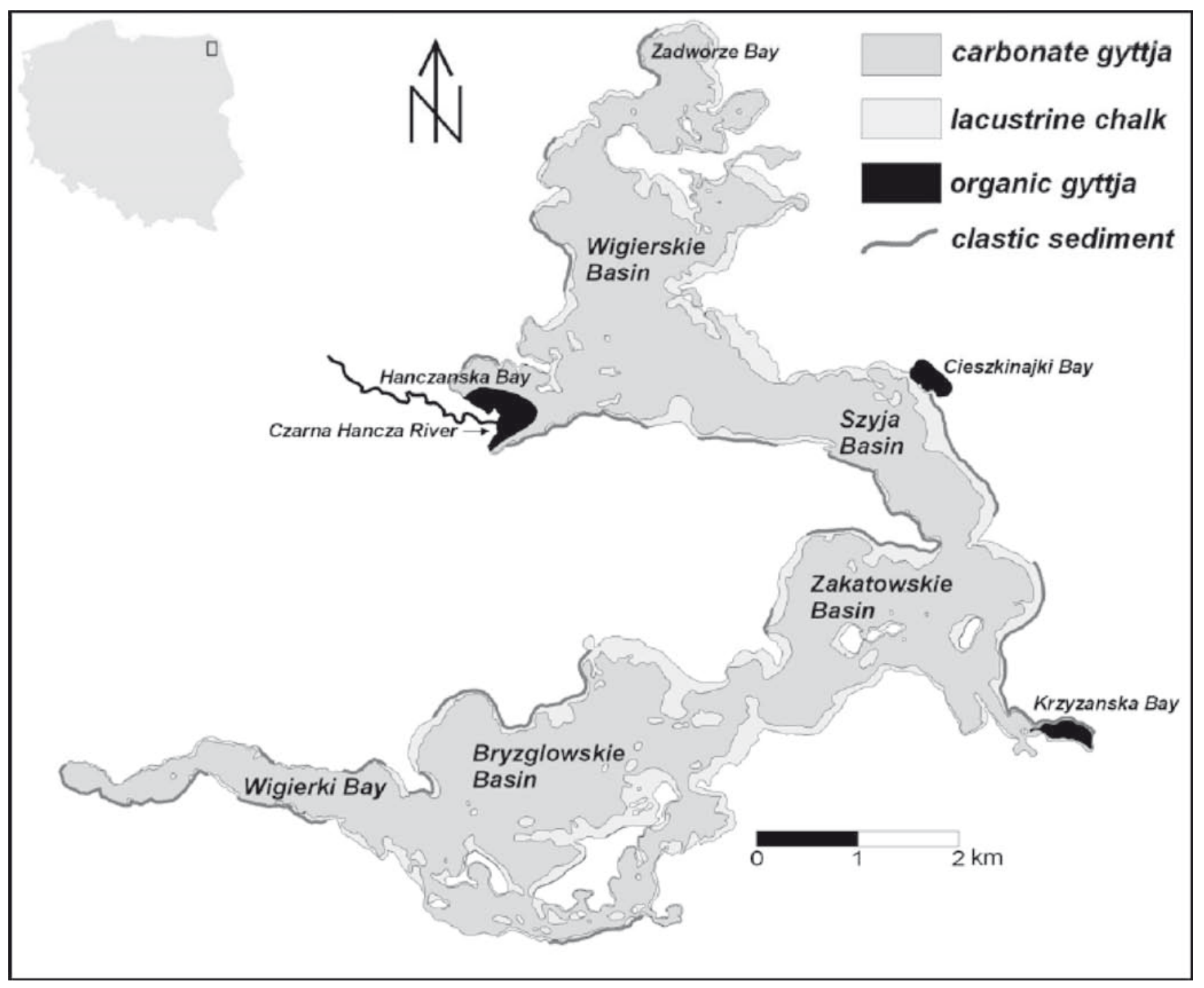

Fig. 1. Types of Lake Wigry sediments (Rutkowski et al. 2009b, modified)

into the lake in its northern basin, and also by some smaller streams, groundwater and precipitations.

Sediments of Lake Wigry show high variability and have been the object of scientific interest from the beginning of the last century (e.g. Stangenberg 1938). Recently they were intensively examined by Rutkowski and others (e.g. Rutkowski and Król 2006; Rutkowski et al. 2002, 2003, 2005, 2006, 2009b, 2009c). In the littoral zone clastic sediment and lacustrine chalk can be found while carbonate gyttja is typical for the profundal zone. Specific organic-reach sediment can be found locally. Recent sediments of Lake Wigry are shown in Fig. 1. Clastic sediment occurs in the form of narrow inshore belts especially below cliffs. In a petrographic composition of this sediment crystalline rocks, limestones and dolomites predominate. The latter two are the main source of $\mathrm{Ca}^{2+}$ in sediments of Lake Wigry. Clastic sediments are also found at the bottom of deep profiles where they underlie carbonate sediments or occur as insertions in those profiles. The littoral zone (about 25$30 \%$ of the lake area) is almost completely covered by lacustrine chalk composed mainly of calcium carbonate (80-95\%) with a slight admixture of organic matter and/or clastic sediment which can differ in particular parts of the lake. Lacustrine chalk is also found in bottom parts of long profiles. It usually underlies carbonate gyttja which covers the recent profundal zone of the lake. Lacustrine chalk also occurs very often in lower parts of under-peatland profiles taken from the vicinity of contemporary Lake Wigry (Fig. 2). These profiles are located in the area of paleolakes, covered now by peats (Rutkowski et al. 2009b). Calcium carbonate building 
lacustrine chalk is precipitated with the participation of water macrophytes and also in a chemical way. Profundal sediment - carbonate gyttja - covers about $60-75 \%$ of the lake area and consists mainly of calcium carbonate (max $70 \%)$ with a significant admixture of organic matter. This type of sediment is quite homogeneous but in general carbonate gyttja of the northern part of the lake contains more organic matter than that of the southern part. Some specific sediment occurs locally (Hańczańska Bay, Cieszkinajki Bay and Krzyżańska Bay) (Fig. 1). This sediment is rich in organic matter, very poor in calcium carbonate and very loose. Sediments of the Hańczańska Bay are rich in poorly decomposed remains mainly of water macrophytes brought by the Czarna Hańcza River, therefore this specific sediment can be called river-lake like (Rutkowski et al. 2009c).

The aim of this work was to determine $\mathrm{Pb}$ content in Lake Wigry sediments taking into consideration lithology and localization of samples, as a specific indicator of changes in the lake environment.

The presented surveys were carried out mostly for bottom sediment of Lake Wigry but also for fossil lake sediment coming from under-peatland profiles (Fig. 2). Also two drillings which allowed over 5 $\mathrm{m}$ long cores to be obtained were performed. They are localized in the area of the Bryzglowskie Basin and called deep profiles (Fig. 2).

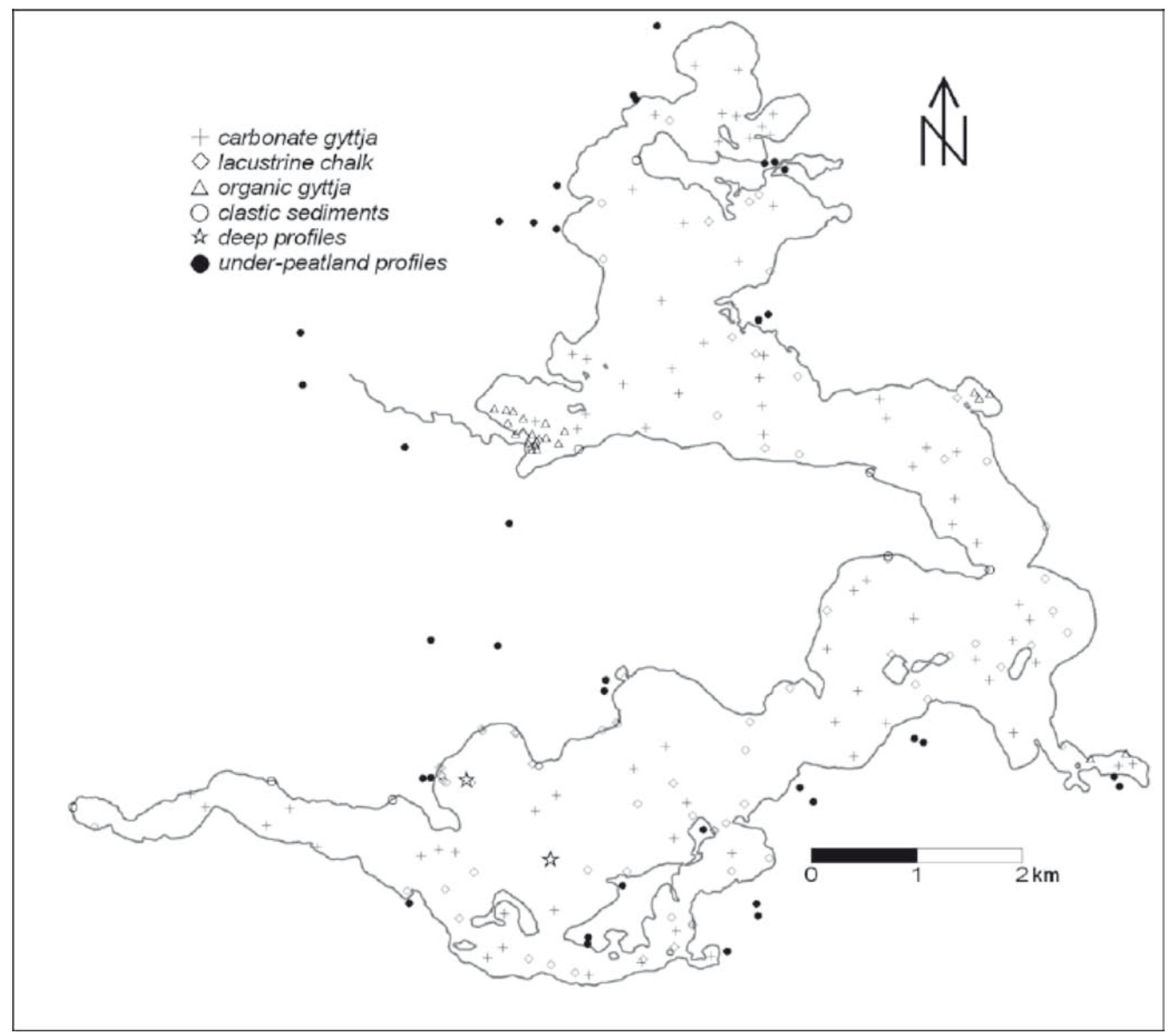

Fig. 2. Study area and localization of sampling sites 


\section{Methods}

Sediment samples were taken during the summer time through several consecutive years by a gravity sampler which allows cores of different length (dozens of $\mathrm{cm}$ ) to be taken depending on local conditions (Rutkowski 2007). Under-peatland cores were taken using an Instorf sampler. Their locations were determined by a GPS and the depth of water using an echosounder (FCV, Furuno). Sediment cores were sliced into segments according to the lithology. Most of the analyses were focused on the surface layer $(0-10 \mathrm{~cm})$ representing recent sediment, in order to determine the spatial distribution of $\mathrm{Pb}$ in the lake. For selected sediment cores the concentration of $\mathrm{Pb}$ in every separated layer was determined to analyse the vertical distribution of this element.

Water content, wet density as well as horizontal shrinkage were determined in the laboratory of Wigierski National Park in Krzywe (near Suwałki city). Other analyses were performed on dried material in the laboratory of the University of Science and Technology in Krakow. Organic matter content was estimated by the weighing method $\left(\mathrm{LOI}, 550^{\circ} \mathrm{C}, 4 \mathrm{~h}\right)$ and $\mathrm{CaCO}_{3}$ content by volumetric (Scheibler's apparatus) and weighting (LOI, $925^{\circ} \mathrm{C}, 4 \mathrm{~h}$ ) methods. Lead content was determined after extraction with a mixture of 10 $\mathrm{ml}$ of $65 \% \mathrm{HNO}_{3}$ and $2 \mathrm{ml} 30 \% \mathrm{H}_{2} \mathrm{O}_{2}$ in a microwave oven (MDS 2000) using the ICP-MS method (Perkin Elmer ELAN 6100) in a certified Hydro-geochemical Laboratory (AGH University, Krakow) according to the standard certified analytical quality control procedure (PN-EN ISO 17294-1:2007). Standard reference material (LKSD-4 - Lake Sediment Reference Material) was employed to determine the accuracy of $\mathrm{Pb}$ analyses.

\section{Results}

Surface sediment. Concentrations of lead in the surface sediment of Lake Wigry range from 2.52 to
$469 \mathrm{mg} \mathrm{kg}^{-1}$. One of the most important factor influencing the spatial distribution of $\mathrm{Pb}$ is type of sediment. The highest concentration of this metal was found in organic gyttja sample and the lowest one in carbonate gyttja (Table 1). Comparison of mean $\mathrm{Pb}$ concentrations in four types of Lake Wigry sediment shows that the least contaminated sediment of the lake is clastic one and the most - organic gyttja. Average lead concentrations in lacustrine chalk, carbonate gyttja and organic gyttja are quite similar which is not typical regarding other metals $(\mathrm{Cd}, \mathrm{Cr}, \mathrm{Cu}, \mathrm{Fe}, \mathrm{Mn}$, $\mathrm{Zn}$ ), examined in earlier papers (Kostka et al. 2008; Prosowicz 2008; Prosowicz et al. 2009). Differences between mean concentrations of these metals in every type of sediment are even greater than one order of magnitude (Kostka 2009). The most significant fact is that lacustrine chalk is clearly enriched in lead in comparison with carbonate gyttja. Earlier studies focused on other metals (Prosowicz et al. 2009) showed that lacustrine chalk (sometimes clastic sediment) is the least polluted sediment type in Lake Wigry. The above results suggest that lead in a water environment behaves a little bit differently than the metals examined before, which is probably the result of its different geochemical properties.

Sediment cores. When analysing changes in selected parameters with depth in sediment cores, it can be found that sediment slices coming from the deeper layers of cores contain more calcium carbonate, less water and have a greater wet density than those that represent recent bottom sediment. Generally the most visible vertical variation occurs in carbonate gyttja cores taken from the profundal zone. The highest concentrations of $\mathrm{Pb}$ were found in the cores taken from two bays: Hańczańska Bay and Zadworze Bay, and the lowest ones in cores from Zakątowskie Basin and Bryzglowskie Basin.

Taking into consideration results from two deep profiles located in the Bryzglowskie Basin (Fig. 2) some

Table 1. Statistical parameters of $\mathrm{Pb}$ concentrations in different sediment types of Lake Wigry

\begin{tabular}{|l|c|c|c|c|}
\hline \multirow{2}{*}{ value } & \multicolumn{3}{|c|}{$\left.\mathrm{Pb} \mathrm{[mg} \mathrm{kg}{ }^{-1}\right]$} \\
\cline { 2 - 5 } & $\begin{array}{c}\text { clastic sediments } \\
(n=8)\end{array}$ & $\begin{array}{c}\text { lacustrine chalk } \\
(n=76)\end{array}$ & $\begin{array}{c}\text { carbonate gyttja } \\
(n=87)\end{array}$ & $\begin{array}{c}\text { organic gyttja } \\
(n=30)\end{array}$ \\
\hline Min. & 6.97 & 6.75 & 2.52 & 19.3 \\
\hline Mean & 23.0 & 71.1 & 55.6 & 120 \\
\hline Max. & 63.8 & 88.1 & 98.0 & 469 \\
\hline SD & 19.1 & 14.5 & 19.2 & 97.5 \\
\hline
\end{tabular}


general trends can be observed: in surface layers of cores high concentrations of $\mathrm{Pb}\left(\max 469 \mathrm{mg} \mathrm{kg}^{-1}\right)$ occur, then decrease in the middle and rise again coming into the bottom parts of cores (Fig. 3). The lower parts of these deep profiles represent the oldest sediment of Lake Wigry coming from the beginning of the lake basin formation. The middle parts of the profiles contain not only the lowest, but also the least varied amounts of $\mathrm{Pb}$ in the whole profiles.

Sediment cores taken from paleolakes (Fig. 2) are characterized by specific sediment parameters as well as specific vertical distribution of $\mathrm{Pb}$. Part of these cores is built with consolidated lacustrine chalk, under which clastic sediment of glacial origin occurs. In some profiles an additional level of carbonate or organic gyttja can be found (Fig. 4). A specific type of deposits is found under enclosed bays where almost the whole thickness of sediment is highly organic, and almost not at all calcareous.

$\mathrm{Pb}$ content in this sediment differs, depending on the location and lithological type of sediment. The highest $\mathrm{Pb}$ concentration occurs in organic gyttja and the lowest one in lacustrine chalk (Table 2). In general average concentration of $\mathrm{Pb}$ in sediment of under-peatland cores (paleolakes areas) is lower than in cores coming from the basin of the recent lake.

Table 2. Statistical parameters of $\mathrm{Pb}$ concentrations in different under-peatland sediment types

\begin{tabular}{|l|c|c|c|c|}
\hline \multirow{2}{*}{ value } & \multicolumn{4}{|c|}{$\mathrm{Pb} \mathrm{[mg} \mathrm{kg-1]}$} \\
\cline { 2 - 5 } & $\begin{array}{c}\text { clastic sediments } \\
(n=3)\end{array}$ & $\begin{array}{c}\text { lacustrine chalk } \\
(n=28)\end{array}$ & $\begin{array}{c}\text { carbonate gyttja } \\
(n=8)\end{array}$ & $\begin{array}{c}\text { organic gyttja } \\
(n=12)\end{array}$ \\
\hline Min. & 2.06 & 0.155 & 0.221 & 0.651 \\
\hline Mean & & 1.28 & 1.09 & 4.14 \\
\hline Max. & 12.1 & 7.08 & 2.90 & 16.9 \\
\hline SD & & 1.87 & 1.07. & 4.77 \\
\hline
\end{tabular}

A

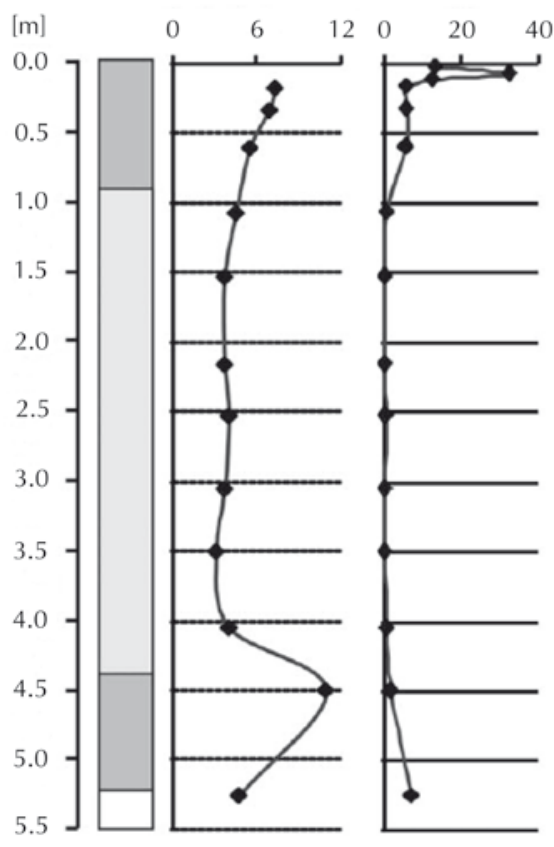

river-lake sediment

$\mathrm{Pb}$

[mg kg-1]
B

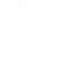

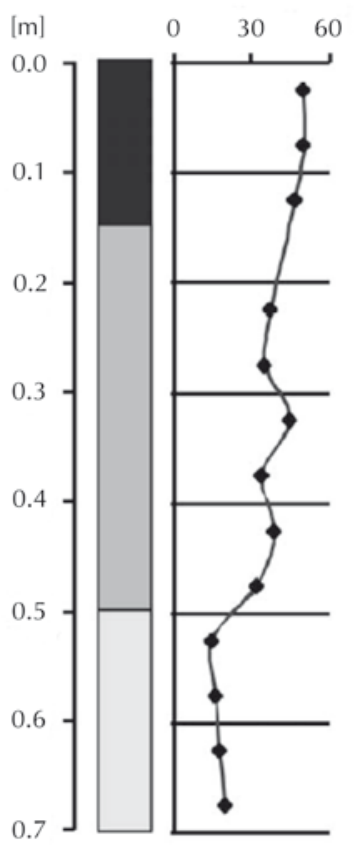

lacustrine chalk
$\mathrm{Pb}$

[mg kg-1]

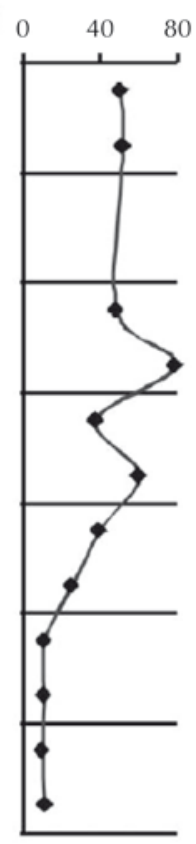

clastic sediment

Fig. 3. Vertical distribution of $\mathrm{Pb}$ in selected sediment cores taken from Lake Wigry (A - deep profile, $\mathrm{B}$ - short profile coming from the Czarna Hańcza river estuary) 


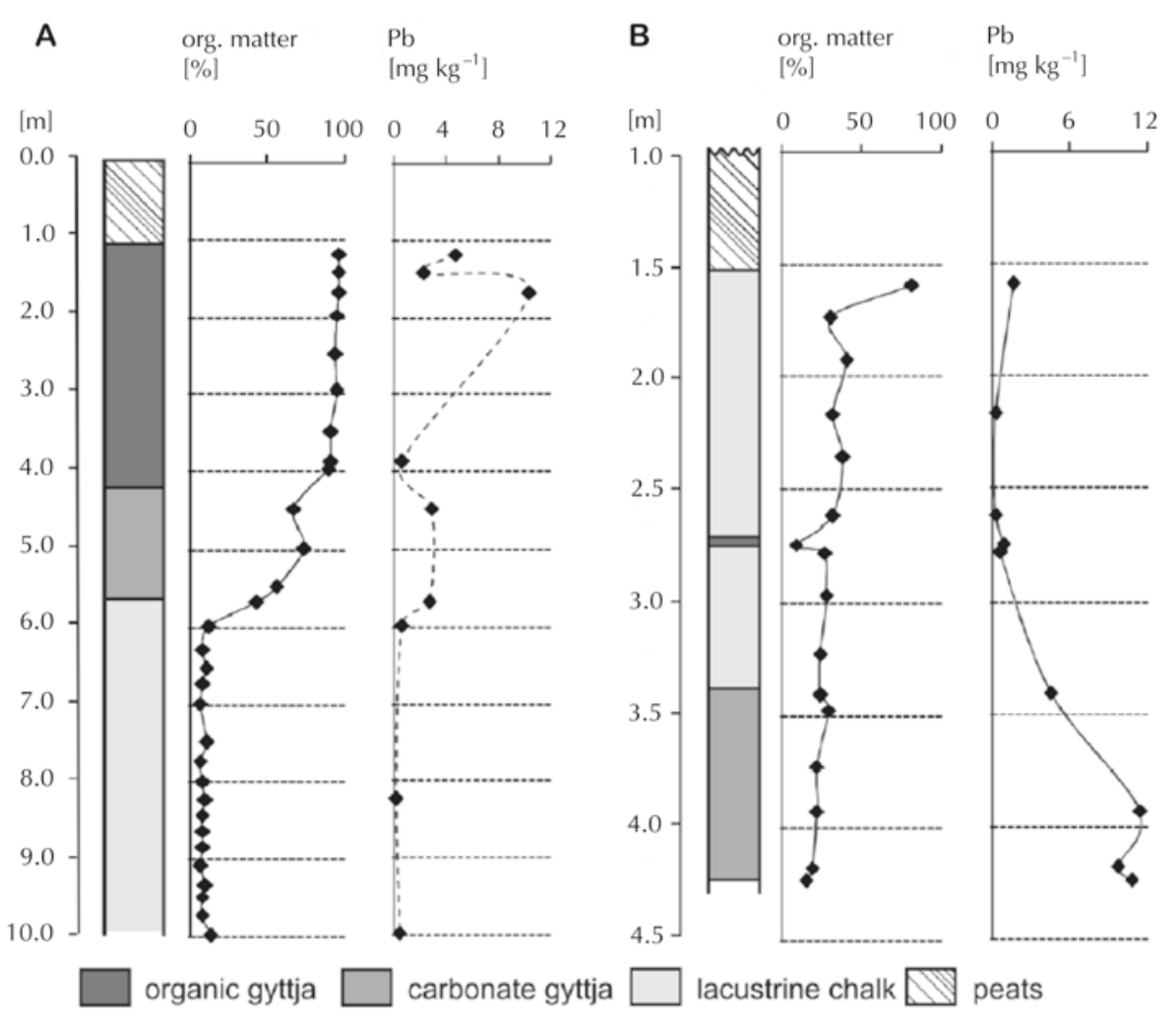

Fig. 4. Vertical distribution of $\mathrm{Pb}$ in selected sediment cores taken from under-peatland areas surrounding Lake Wigry

\section{Discussion}

Lead is the most interesting metal examined in Lake Wigry sediment, regarding its specific geochemical properties. Moreover, its concentrations in the lake are significant. In order to evaluate metal contamination of the lake sediments, different values of geochemical background were used. All earlier concentrations of the studied metals exceed those values, often greatly (Kostka 2009). However when comparing results with widely used bottom sediment classification - according to the geoaccumulation index $\left(\mathrm{I}_{\text {geo }}\right)$ (Müller 1981) - bottom sediments of Lake Wigry seem to be uncontaminated (class 0 ). Lead is an exception which obliges us to classify sediments into I and/or II class. The origin of lead in Lake Wigry sediments can be partially natural and it may come from weathering of postglacial sediments densely covering the lake surroundings. However some, probably meaningful part of $\mathrm{Pb}$ in water sediments comes from human activity, like transportation, waste or even ammunition used during the Second World War.
In the $\mathrm{Pb}$ accumulation in sediment, the most important role is played by processes of sorption, when compared with processes of precipitation or co-precipitation (Davis and Galloway 1993). Naturally occurring $\mathrm{Pb}$ is commonly associated with fine grained Fe-Al silicates (Salomons and Forstner 1984). $\mathrm{Pb}$ deposited from the atmosphere is associated with organic matter in the catchment (Bergqvist et al. 1989) and in runoff water (Borg and Johansson 1989). These references support the finding that $\mathrm{Pb}$ content in preindustrial sediment is mainly dependent on the geochemistry in the catchment.

Lead is a poorly mobile metal and is hardly remobilized from sediment (Hamilton-Taylor and Davison 1995). During conditions of low $\mathrm{pH}, \mathrm{Pb}$ forms complexes with organic matter whereas in $\mathrm{pH}>6.5$ lead is immobilized in carbonates and phosphates (Kabata-Pendias and Pendias 1999). It is also known that $\mathrm{Pb}$ released in weathering processes is accumulated in carbonates and carbons (Dojlido 1995). In the light of the above facts it seems to be clear why $\mathrm{Pb}$, in contrast to other trace elements, is especially 


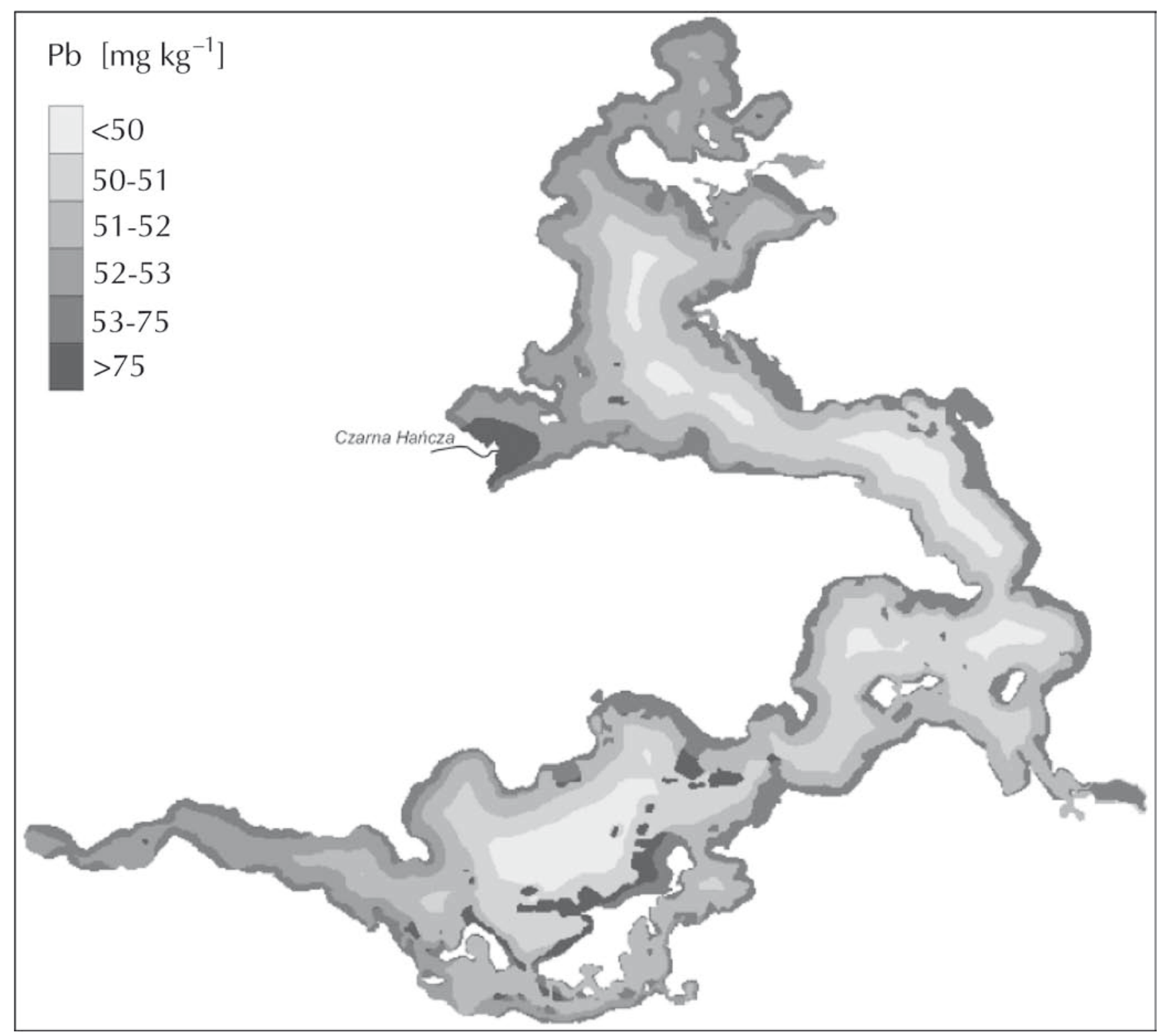

Fig. 5. Spatial distribution of $\mathrm{Pb}$ in recent bottom sediments of Lake Wigry

accumulated in lacustrine chalk (Fig. 5). This type of sediment distinguishes itself by its alkaline environment and is the first catch for metals coming to the lake with surface flow. Carbonate gyttja is also rich in calcium carbonate but the profundal zone covered by this kind of sediment is characterized by lower $\mathrm{pH}$ than the littoral zone. On the other hand organic gyttja, especially from the Czarna Hańcza estuary, is most of all enriched in $\mathrm{Pb}$. This type of sediment is poor in calcium carbonate but rich in organic matter which also facilitates bonding of metals. The Czarna Hańcza estuary is also the first area of dropping of contaminations, carried by the Czarna Hańcza River from the whole catchment (Migaszewski et al. 2003). The type of sediment least contaminated with $\mathrm{Pb}$ is clastic (poor in organic matter and poor in calcium carbonate). This result is similar to earlier papers referring to other heavy metals like $\mathrm{Cd}, \mathrm{Cr}, \mathrm{Cu}, \mathrm{Fe}, \mathrm{Mn}, \mathrm{Zn}$ (Kostka et al. 2008; Prosowicz 2008; Prosowicz et al. 2009).

In long cores, the higher content of $\mathrm{Pb}$ in the deepest sandy layers of profiles is connected with an admixture of crystalline rocks and intensive surface washout existing during initial phases of Lake Wigry's formation. The middle part of profiles was formed in the time when the terrain was fully covered by forest (Aleksander-Kwaterczak 2009; Aleksander-Kwaterc- 
zak et al.2009) and slow carbonate sedimentation took place. The progressive increase of $\mathrm{Pb}$ concentration upwards in the profiles may be caused by deforestation and increase in agricultural activity (AleksanderKwaterczak 2009; Aleksander-Kwaterczak et al. 2009). The rapid increase in lead content in the uppermost sediment layer is caused by an increase in industrial activity, the degree of eutrophication and the binding of $\mathrm{Pb}$ by intensely accumulated organic matter. $\mathrm{Pb}$ concentrations in Lake Wigry sediment show high linear correlation $(r=0.7)$ with organic matter content. Therefore, the origin of $\mathrm{Pb}$ in the bottom sediment of Lake Wigry is partly natural (associated with washing out of postglacial, crystalline and carbonate sediment or with forest fires) and partly anthropogenic (transportation, sludge, waste/wild dumps).

In order to compare the average content of $\mathrm{Pb}$ and other metals examined in earlier papers with other lakes in Poland and in the world, some data were collected and presented in Table 3. It can be observed that regarding $\mathrm{Cd}, \mathrm{Cr}, \mathrm{Cu}, \mathrm{Fe}, \mathrm{Mn}$ and $\mathrm{Zn}$ concentrations, Lake Wigry is less contaminated than other lakes mentioned. However when lead is taken into consideration, it can be seen that its content in Wigry sediments is higher than in most of the other lakes.

\section{Conclusions}

Comparing average concentrations of selected metals in the sediment of Lake Wigry with other lakes in Poland and worldwide, it can be concluded that Lake Wigry is generally unpolluted and slightly contaminated regarding $\mathrm{Pb}$. The highest lead content found in the surface layers of sediment is mainly the effect of anthropogenic activity. In Lake Wigry sediments lying deeper, the clear influence of postglacial sediment lithology is visible. Concentrations of elements in fossil lake sediment can be taken as the local geochemical background. When analysing factors affecting spatial distribution of lead in sediment, it was found that the enrichment in heavy metals may have both a natural and anthropogenic origin.

\section{Acknowledgments}

These studies were carried out within the project of the Faculty of Geology, Geophysics and Environment Protection at the AGH University of Science and Technology in Krakow (11.11.140.447, 15.11.140.075). The study was possible only thanks to the kindness of J. Rutkowski and the staff of the Wigierski National Park.

Table 3. Comparison of average concentrations of metals in sediment of different lakes. Shaded cells - values lower than in Lake Wigry

\begin{tabular}{|c|c|c|c|c|c|c|c|c|}
\hline \multirow{2}{*}{ lake/lakes } & $\mathrm{Cd}$ & $\mathrm{Cr}$ & $\mathrm{Cu}$ & $\mathrm{Fe}$ & $\mathrm{Mn}$ & $\mathrm{Pb}$ & $\mathrm{Zn}$ & \multirow{2}{*}{ references } \\
\hline & \multicolumn{7}{|c|}{$\mathrm{mg} \mathrm{kg}^{-1}$} & \\
\hline Lake Wigry (Poland) & 0.173 & 2.3 & 3.05 & 1755 & 166 & 69.8 & 27.5 & Kostka 2009 \\
\hline Lake Hańcza (Poland) & - & 4.5 & 10 & 9300 & 961 & 26.5 & 68.2 & Choiński et al. 1999 \\
\hline Lake Góreckie (Poland) & 3.35 & 9.86 & 12.1 & 9218 & 347 & 47.5 & 63.7 & Sobczyński et al. 1996b \\
\hline $\begin{array}{l}11 \text { lakes of Wielkopolski National Park } \\
\text { (Poland) }\end{array}$ & 4.5 & 11.3 & 15.1 & 8730 & 537 & 52.3 & 85.7 & $\begin{array}{l}\text { Sobczyński et al. 1996a, } \\
\text { Sobczyński and Siepak } 2001\end{array}$ \\
\hline Lake Zegrzyńskie (Poland) & - & 59 & 23 & 14511 & 565 & - & 83 & Taboryska and Dojlido 2001 \\
\hline Lake Dąbie (Poland) & 11.5 & - & 119 & - & - & 200 & 1122 & Piotrowski 1997 \\
\hline $\begin{array}{l}48 \text { lakes of Kaszuby Lake Region } \\
\text { (Poland) }\end{array}$ & 0.7 & 18 & 11 & - & - & 36 & 126 & Bojakowska and Sokołowska 1996 \\
\hline Lake Rożnowskie (Poland) & 0.404 & 52.4 & 32 & - & 1621 & 23.3 & 118 & $\begin{array}{l}\text { Skwarczek and Helios-Rybicka 2004; } \\
\text { Skwarczek } 2005\end{array}$ \\
\hline Szczeciński Bay (Poland) & - & 59.6 & 55.3 & 33000 & 2179 & 106 & 856 & Osadczuk 2004 \\
\hline 49 lakes of Latvia & 1.18 & - & 6.69 & - & 50.6 & 23.7 & 48.5 & Kļaviņš et al. 1995 \\
\hline Lake Macquarie (Australia) & 1.43 & - & 26.6 & - & - & - & 127 & Kirby et al. 2001 \\
\hline Lake Srebarna (Bulgaria) & 0.6 & 117 & 52.6 & 25300 & - & 183 & 130 & Ricking and Terytze 1999 \\
\hline Jauá Lake (Brazil) & - & - & 149 & 169295 & - & 99.5 & 964 & da Silva et al. 2000 \\
\hline Lakes of south Norway & 0.7 & 20.5 & 32.3 & 53700 & 240 & 131 & 155 & Rognerud et al. 2000 \\
\hline Lake Rőuge Liinjärv (Estonia) & - & - & 13.9 & - & 470 & 13.6 & 37.4 & Lepane et al. 2007 \\
\hline Lakes of Texas (USA) & 0.27 & - & 21.1 & 34367 & 512 & 24 & - & Menounou and Presley 2003 \\
\hline
\end{tabular}




\section{References}

Aleksander-Kwaterczak U., 2007, Rozmieszczenie metali śladowych w rdzeniach osadów wybranych rzek Polski (Distribution of trace metals in sediment cores of selected rivers of Poland), Wyd. AGH, Kraków, p. 114 (in Polish).

Aleksander-Kwaterczak U., 2009, Record of natural environment of Lake Wigry changes on the basis of long sediment cores analysis, [in:] Marszelewski W. (ed.) Anthropogenic and natural transformations of lakes, Vol. 3, pp. 11-15.

Aleksander-Kwaterczak U., Prosowicz D., Rutkowski J., Szczepańska J., 2009, Changes of selected micro-pollution concentrations in the long carbonate sediment cores of the southern part of Lake Wigry (NE Poland), Pol. J. Environ. Stud. 18(2): 51-55.

Bergkvist B., Folkeson L., Berggren D., 1989, Fluxes of Cu, $\mathrm{Zn}, \mathrm{Pb}, \mathrm{Cd}, \mathrm{Cr}$ and $\mathrm{Ni}$ in temperate forest ecosystem. A literature review, Water Air Soil Poll. 47: 217-286.

Bojakowska I., 1995, Wpływ odprowadzania ścieków na akumulację metali ciężkich w osadach wybranych rzek Polski (Influence of sewerage on heavy metals accumulation in sediment of selected rivers of Poland), PIG, Instrukcje i Metody badań geologicznych 55, Warszawa, p. 78 (in Polish).

Bojakowska I., Sokołowska G., 1996, Metale ciężkie w osadach jezior Pojezierza Kaszubskiego (Heavy metals in lake sediment of Kaszuby Lake Region), Prz. Geol. 44(9): 920-923 (in Polish, English summary).

Borg H., Johansson K., 1989, Metal fluxes to Swedish forest lakes, Water Air Soil Poll. 47: 427-440.

Choiński A., Grzebisz W., Skowron R., 1999, Chemizm osadów dennych jeziora Hańcza (Chemistry of Hańcza Lake sediment), [in:] Choiński A., Jańczak J. (eds) Naturalne i antropogeniczne przemiany jezior (Natural and anthropogenic transformations of lakes), IMGW, Warszawa: 27-33 (in Polish).

da Silva E.M., Navarro M.F.T., Barros A.F., Mota M.F.V., Chastinet C.B.A., 2000, Metals in the sediments of Jauá Lake (Camaçari, Bahia, Brazil) following an episode of industrial contamination, Aquat. Ecosyst. Health 3: 509514.

Davis A., Galloway J.N., 1993, Distribution of Pb between sediment and pore water in Woods Lake, Adirondack State Park, New York, U.S.A., Appl. Geochem. 8: 51-65.

Dojlido J.R., 1995, Chemia wód powierzchniowych (Chemistry of surface waters), Wyd. Ekonomia i Środowisko, Białystok, p. 342 (in Polish).

Hamilton-Taylor J., Davison W., 1995, Redox-Driven Cycling of Trace Elements in Lakes, [in:] Lerman A., Imboden D., Gat J. (eds), Physics and Chemistry of Lakes, Springer-Verlag, Berlin: 217-263.

Jańczak J. (ed.), 1999, Atlas jezior Polski, t. 3 (Atlas of Polish Lakes, vol. 3), Bogucki Wyd. Nauk., Poznań, p. 240 (in Polish).
Kabata-Pendias A., Pendias H., 1999, Biogeochemia pierwiastków śladowych (Biogeochemistry of trace elements), Wyd. Nauk. PWN, Warszawa, p. 400 (in Polish).

Kirby J., Maher W., Krikowa F., 2001, Selenium, Cadmium, Copper, and Zinc Concentrations in Sediments of Mullet (Mugil cephalus) from the Southern Basin of Lake Macquarie, NSW, Australia, Arch. Environ. Con.Tox. 40: 246-256.

Kḷavinšs M., Briede A., Kḷaviņa I., Rodinov V., 1995, Metals in sediments of lakes in Latvia, Environ. Int. 21(4): 451-458.

Kostka A., 2009, Ocena zmienności przestrzennej metali śladowych w osadach dennych jeziora Wigry z wykorzystaniem technik GIS (Assessment of spatial variability of trace metals in bottom sediments of Lake Wigry with a use of GIS techniques) [Dissertation], Akademia Górniczo-Hutnicza, Wydział GGiOŚ, Kraków, p. 127 (in Polish).

Kostka A., Prosowicz D., Aleksander-Kwaterczak U., 2008, Zmienność przestrzenna zawartości żelaza i manganu w osadach jeziora Wigry (Spatial variability of iron and manganese content in sediment of Lake Wigry), Pr. Kom. Paleogeogr. Czwartorz. PAU 6: 145-152 (in Polish). Lepane V., Varvas M., Viitak A., Alliksaar T., Heinsalu A., 2007, Sedimentary record of heavy metals in Lake Rőuge Liinjärv, southern Estonia, Estonian J. Earth Sci. 56(4): 224-232.

Macklin M., Klimek K., 1992, Dispersal, storage and transformation of metal - contaminated alluvium in the upper Vistula Basin, southwest Poland, Appl. Geogr.12: 7-30. Marszalewski W., 2005, Zmiany warunków abiotycznych w jeziorach Polski północno-wschodniej (Changes of abiotic conditions in lakes of NE Poland), Wyd. UMK, Toruń, p. 288 (in Polish, English summary).

Menounou N., Presley B.J., 2003, Mercury and Other Trace Elements in Sediment Cores from Central Texas Lakes, Arch.Environ. Con.Tox. 45: 11-29.

Migaszewski Z. M., Gałuszka A., Pasławski P., 2003, Baseline versus background concentrations of trace elements in sediments of Lake Wigry, NE Poland, Limnol. Rev. 3: 165-172.

Müller G., 1981, Schwermetallbelasturg der Sedimente des Neckar und seiner Nebenflüsse: Eine Bestandsaufnahme, Chemiker-Zeitung. -Chemie, Technische Chemie, Chemiewirtschaft 105(6): 157-164.

Nriagu J.O., 1996, A history of global metal pollution, Science, 272: 223-224.

Osadczuk A., 2004, Zalew Szczeciński - środowiskowe warunki współczesnej sedymentacji lagunowej (Oder Lagoon - environmental conditions of contemporary lagoon sedimentation), Wyd. Nauk. USz, Szczecin, p. 156 (in Polish).

Osadczuk A., Rutkowski J., Krzysztofial K., 2006, Zróżnicowanie dna południowej części jeziora Wigry w świetle badań z zastosowaniem akustycznego systemu RoxAnn (Diversification of southern part of Lake Wigry bottom in the ligtht of examination with a use of the acustic system RoxAnn), Pr. Kom. Paleogeogr. Czwartorz. PAU 3: 179-185 (in Polish). 
Piotrowski S., 1997, Zawartość metali ciężkich w wybranych elementach ekosystemu jeziora Dąbie (NW Polska) (Heavy metals content in selected elements of Lake Dąbie ecosystem (NE Poland)), Prz. Geol. 45(6): 619-621 (in Polish, English summary).

Prosowicz D., 2008, Metale w osadach dennych jeziora Wigry (Metals in bottom sediment of Lake Wigry), Geologia 34(1): 85-108 (in Polish, English summary).

Prosowicz D., Aleksander-Kwaterczak U., Kostka A., 2009, Metale śladowe $\mathrm{w}$ osadach jeziora Wigry (Trace metals in the sediment of Lake Wigry), [in:] Rutkowski J., Krzysztofiak L. (eds), Jezioro Wigry. Historia jeziora w świetle badań geologicznych i paleoekologicznych (Lake Wigry. History of the lake in the light of geological and paleoecological studies), Stow. "Człowiek i Przyroda", Suwałki: 110-130 (in Polish).

Ricking M., Terytze K., 1999, Trace metals and organic compounds in sediment samples from the River Danube in Russe and Lake Srebarna (Bulgaria), Environ. Geol. 31(1-2): 40-46.

Rognerud S., Hongve D., Fjeld E., Ottesen R.T., 2000, Trace metal concentrations in lake and overbank sediments in southern Norway, Environ. Geol. 39(7): 723-732.

Rutkowski J., 2007, Simple gravity sampler for taking cores from lake sediment, [in:] Kubiak J., Bajkiewicz-Grabowska E. (eds), Anthropogenic and natural transformations of lakes, vol.1, Agricultural University of Szczecin, Polish Limnological Society, Szczecin: 108-109.

Rutkowski J., Pietsch K., Król K., Rudowski S., Krzysztofiak L., 2005, High resolution seismic survey in the Lake Wigry (NE Poland), Peribalticum,9: 147-162.

Rutkowski J., Król K., 2006, Wykształcenie litologiczne osadów z wiercenia WZS-03 w Zatoce Słupiańskiej (jezioro Wigry) (Lithological formation of sediment from WZS03 drilling in Słupiańska Bay (Lake Wigry)), Pr. Kom. Paleogeog. Czwartorz. PAU 3: 187-191 (in Polish).

Rutkowski J., Król K., Krzysztofiak L., Prosowicz D., 2002, Recent sediment of Lake Wigry (Bryzgiel Basin), Limnol. Rev. 2: 353-362.

Rutkowski J., Król K., Krzysztofiak L., Prosowicz D., 2003, Recent sediment of Lake Wigry (Szyja Basin), NE Poland, Limnol. Rev.3: 197-203.

Rutkowski J., Król K., Krzysztofiak L., Prosowicz D., 2006, Mapa osadów pokrywających dno jeziora Wigry (Map of sediment covering the bottom of Lake Wigry), Pr. Kom. Paleogeogr. Czwartorz. PAU 3: 171-178 (in Polish).

Rutkowski J., Krzysztofiak L., Osadczuk A., 2009a, Batymetria i ukształtowanie linii brzegowej (Bathymetry and configuration of coastline), [in:] Rutkowski J., Krzysztofiak L. (eds), Jezioro Wigry. Historia jeziora w świetle badań geologicznych i paleoekologicznych (Lake Wigry. History of the lake in the light of geological and paleoecological studies), Stow. “Człowiek i Przyroda”, Suwałki: 42-53 (in Polish).
Rutkowski J., Pietsch K., Osadczuk A., Krzysztofiak L., 2009b, Osady jeziora Wigry w świetle badań sejsmicznych (Seismic Survey of Lake Wigry Sediment), [in:] Rutkowski J., Krzysztofiak L. (eds), Jezioro Wigry. Historia jeziora w świetle badań geologicznych i paleoekologicznych (Lake Wigry. History of the lake in the light of geological and paleoecological studies), Stow. "Człowiek i Przyroda", Suwałki: 131-143 (in Polish).

Rutkowski J., Prosowicz D., Aleksander-Kwaterczak U., Krzysztofiak L., 2009c, Osady jeziora Wigry (Sediment of Lake Wigry), [in:] Rutkowski J., Krzysztofiak L. (eds), Jezioro Wigry. Historia jeziora w świetle badań geologicznych i paleoekologicznych (Lake Wigry. History of the lake in the light of geological and paleoecological studies), Stow. "Człowiek i Przyroda", Suwałki: 83-109 (in Polish).

Salomons W., Förstner U., 1984, Metals in the Hydrocycle, Springer, Berlin, p. 359.

Skwarczek M., 2005, Badanie stanu zanieczyszczenia Jeziora Rożnowskiego metalami śladowymi oraz numeryczne modelowanie transportu zanieczyszczeń z zastosowaniem pakietu Surface-water Modeling System (Examination of haevy metals contamination of Rożnowskie Lake and digital modelling of pollutants transport with a use of Surface-water Modeling System) [Dissertation], Akademia Górniczo-Hutnicza, Wydz. GGiOŚ, Kraków, p. 135 (in Polish).

Skwarczek M., Helios-Rybicka E., 2004, Badania hydro-geochemiczne systemu wodnego Jeziora Rożnowskiego (Hydro-geochemical examination of water system of Rożnowskie Lake), Geologia 30(2): 207-214 (in Polish, English summary).

Sobczyński T., Zerbe J., Elbanowska H., Siepak J., 1996a, Badania chemiczne osadów dennych jeziora Góreckiego w aspekcie oceny oddziaływania antropopresji (Chemical examinations of bottom sediments of Góreckie Lake regarding anthropopression), Ekol. Tech. 2: 14-18 (in Polish).

Sobczyński T., Zerbe J., Elbanowska H., Sajewska K., Siepak J., 1996b, Badania chemiczne osadów dennych jezior Wielkopolskiego Parku Narodowego w aspekcie oceny antropopresji (Chemical examinations of bottom sediments of Wielkopolski National Park lakes regarding anthropopression), Ekol. Tech.5/6: 17-22 (in Polish).

Sobczyński T., Siepak J., 2001, Speciation of Heavy Metals in Bottom Sediments of Lakes in Wielkopolski National Park, Pol. J. Environ. Stud. 10(6): 463-474.

Stangenberg M., 1938, Skład chemiczny osadów głębinowych jezior Suwalszczyzny (Chemical composition of bottom sediments of Suwałki Region lakes), Rozpr. Inst. Bad. Lasów Państw. 31A: 5-40 (in Polish).

Taboryska B., Dojlido J.R., 2001, Metale ciężkie w osadach dennych Jeziora Zegrzyńskiego (Heavy metals in bottom sediments of Zegrzyńskie Lake), [in:] Siepak J. (ed.), Problemy analityczne badań osadów dennych (Analytical problems of bottom sediments investigations), Wyd. UAM, Poznań: 7-17 (in Polish). 